\title{
Discovery of Late Cretaceous foraminifera in the Songliao Basin: Evidence from SK-1 and implications for identifying seawater incursions
}

\author{
XI DangPeng ${ }^{1}$, WAN XiaoQiao ${ }^{1 *}$, FENG ZhiQiang ${ }^{2}$, LI Shun, FENG ZiHui ${ }^{2}$,JA JianZhong ${ }^{1}$, \\ JING Xia ${ }^{1} \&$ SI WeiMin ${ }^{1}$ \\ ${ }^{1}$ School of Earth Science and Resources, China University of Geosciences (Beijing), Beijing 100083, China; \\ ${ }^{2}$ Exploration and Development Research Institute of Daqing Oil Field Company, Daqing 163712, China
}

Received September 27, 2010; accepted October 11, 2010

\begin{abstract}
The Songliao Basin is the largest oil-bearing basin in China. In the absence of sufficient evidence, the possibility of seawater incursion(s) into the Songliao Basin remains controversial. Recently, we discovered relatively abundant foraminifera fossils from units 1 and 2 of the Nenjiang Formation of borehole SK-1. Benthic foraminifera (Gavlinella sp., Anomalinoides sp., Pullenia sp., Haplophragmoides sp., Karrorulina hokkaidoana, Clavulinoides sp.), as well as planktonic foraminifera (Archaeoglobigerina blowi, Archaeoglobigerina cretacea and Hedbergella flandrini), were identified. These fossils were widely distributed in the marine Cretaceous. According to the global distribution of the above-mentioned planktonic foraminifera, the age of these fossil bearing strata appears to be Late Coniacian to Santonian. More importantly, these foraminifera provide direct evidence for marine water incursions into the Songliao Basin during deposition of the Lower Nenjiang Formation.
\end{abstract}

foraminifera, seawater incursion, Songliao Basin, SK-1, Nenjiang Formation, Cretaceous

Citation: Xi D P, Wan X Q, Feng Z Q, et al. Discovery of Late Cretaceous foraminifera in the Songliao Basin: Evidence from SK-1 and implications for identifying seawater incursions. Chinese Sci Bull, 2011, 56: 253-256, doi: 10.1007/s11434-010-4269-y

The Songliao Basin, in northeast China, is one of the largest Cretaceous continental rift basins in the world. Two lake transgressions occurred during sedimentation of the Lower Qingshankou and Lower Nenjiang formations, depositing a suite of dark mudstone, black shale and oil shale [1,2]. The possibility of seawater incursions into the Songliao Basin has been debated for more than thirty years [3-14]. Recently, based on bivalves fossils and other evidence, Sha [15] also concluded the possible existence of seawater incursion events in the Songliao Basin. Until now, fossil evidence supporting the hypothesis of seawater incursion has included brackish water fish, bivalves, dinoflagellates and calcareous nannofossils, which may have been associated with seawater, as well as a lack of typical marine fossils. In

*Corresponding author (email: wanxq@cugb.edu.cn) addition, it is difficult to use geochemical parameters to distinguish non-marine and marine environments. As a result, the presence of any marine water incursions was doubted $[10,11]$. Although microfossils in the Songliao Basin have been studied in detail $[7,16,17]$, no foraminifera were discovered previously. Being the most important and widely distributed microfossils in the marine environment during and since the Late Cretaceous, foraminifera have become extremely useful in terms of biostratigraphy, paleoenvironmental reconstruction and in recognition of seawater incursion events.

This report presents the first record of foraminifera in Late Cretaceous age sediments of the Songliao Basin. This discovery will help us to better understand seawater incursion events, paleoenvironment and the formation of hydrocarbon source rocks in this basin. In this paper, we report a 
preliminary study of foraminifera, providing direct evidence for seawater incursion into the Songliao Basin.

\section{Methods and materials}

The China Cretaceous Continental Scientific Drilling Program-Songke 1 (south) borehole (SK-1(s)) is located in the central part of the Songliao Basin (Figure 1). The length of the core is $959.55 \mathrm{~m}$, covering the strata of unit 3 of the Quantou Formation to unit 2 of the Nengjiang Formation [18]. Units 1 and 2 of the Nenjiang Formation (968.17 to $1128.17 \mathrm{~m}$ ) consist mainly of dark mudstones, intercalated with thin carbonate layers, black shales and oil shales.

Samples for microfossil processing were collected at 1-m intervals, on average. Samples of $100 \mathrm{~g}$ dry weight sediments were dispersed in deionised water for several weeks prior to sieving through a $200 \mu \mathrm{m}$ sieve. Foraminifera were picked from the samples under a low-powered binocular microscope, and subsequently stored in micro-paleontological specimen slides. Scanning Electron Microscope (SEM) images of foraminifera were taken at the China University of Geosciences (Beijing).

\section{Composition and characteristics of foraminafera}

Hundreds of foraminifera tests were picked from the samples, but only relatively well preserved fossils were identified in this study. The cored sediments contained 9 species in 8

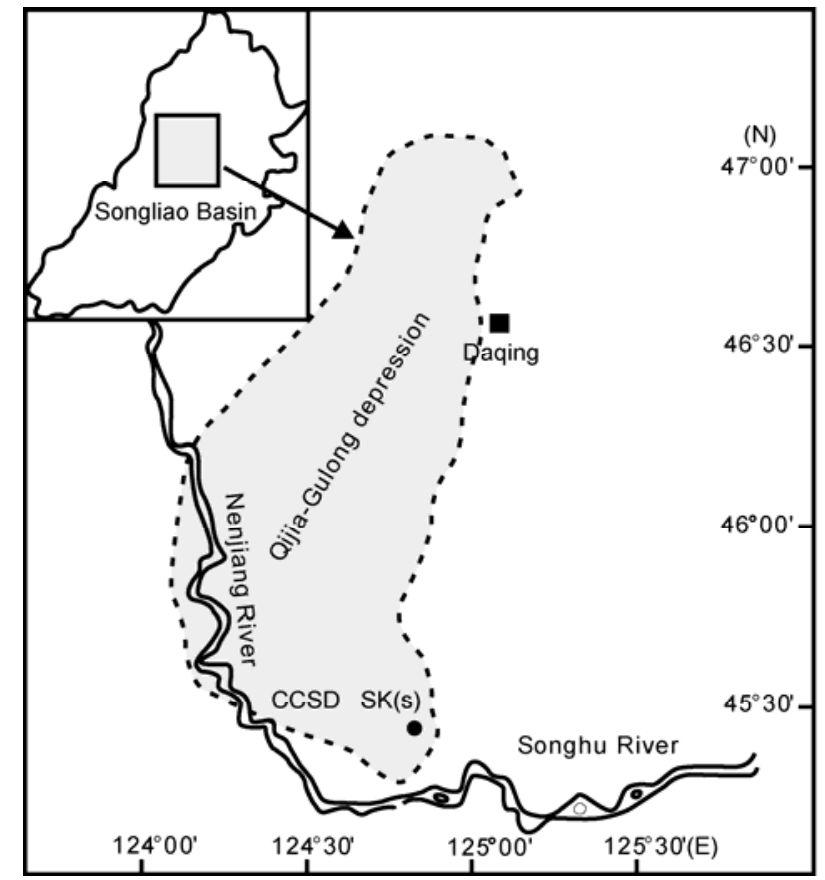

Figure 1 Sketch map showing the study area in the Songliao Basin. genera. Benthic calcareous foraminifera (Gavlinella sp., Anomalinoides sp., Pullenia sp.), benthic agglutinated foraminifera (Haplophragmoides sp., Karrorulina hokkaidoana, Clavulinoides sp.), and planktonic foraminifera (Archaeoglobigerina blowi, Archaeoglobigerina cretacea and Hedbergella flandrini) were identified (Figure 2). The main characteristics of the foraminifera were (1) Foraminiferal tests were $0.2-0.5 \mathrm{~mm}$ in size, and a few agglutinated shells were up to $1 \mathrm{~mm}$. Most of the foraminifera were calcareous, with only a small portion preserved as agglutinated tests. Furthermore, there were many planktonic foraminifera specimens. (2) Most of the foraminiferal tests were well preserved, with some pressed flat. In addition to agglutinated tests and a few calcareous tests, the other foraminifera were brownish in color. (3) Abundances of foraminifera were relatively high, with more than 100 tests/100 $\mathrm{g}$ in some samples. The diversity of foraminifera was moderate, including benthic calcareous foraminifera, agglutinated foraminifera and planktonic foraminifera. (4) Foraminiferal fauna in the Songliao Basin were similar to those of typical marine species. (5) The foraminifera fossils occurred separately in several layers of units 1 and 2 of the Nenjiang Formation.

\section{Age of planktonic foraminifera}

Planktonic foraminifera (Archaeoglobigerina blow, Archaeoglobigerina cretacea and Hedbergella flandrini) were discovered and constrain the age of lower unit 1 of the Nenjiang Formation. Archaeoglobigerina blowi ranges from the late Coniacian to Maastrichtian, Archaeoglobigerina cretacea from Coniacian to Maastrichtian, and Hedbergella flandrini from late Turonian to Santonian [19]. Benthic foraminifera found in the Songliao Basin were widely distributed regionally in Upper Cretaceous strata [20]. According to the global distribution of the above mentioned planktonic foraminifera, the lower unit 1 of the Nenjiang Formation appears to be late Coniacian to Santonian in age.

\section{Paleoenvironmental significance}

Foraminifera are marine organisms, although a few benthic foraminifera have been reported from brackish or saline lakes [21-26]. Brackish and saline lake settings normally have limited foraminiferal representatives, such as Nonion, and are characterized by lower specimen diversities, individuals with abnormal tests and absence of planktonic foraminifera [24]. Planktonic foraminifera are indicators of normal marine facies. Foraminifera in the Songliao basin represent various types, especially planktonic foraminifera. These species were distributed worldwide in marine Cretaceous sediments [19]. Almost all of the planktonic and benthic foraminifera are known from the northwest Pacific 


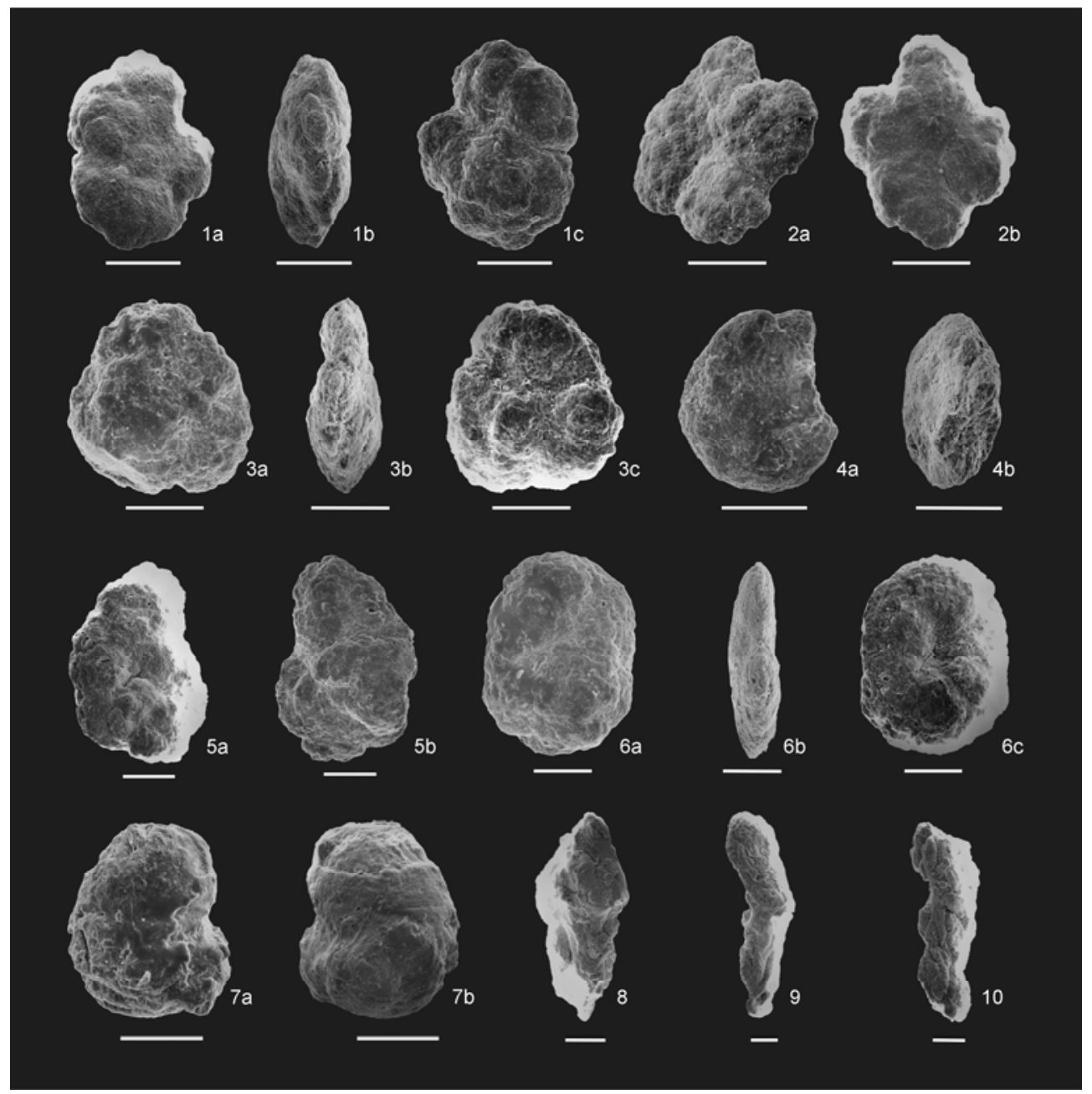

Figure 2 SEM photomicrographs of foraminifera from SK-1(s). The scale bar for all species is $200 \mu \mathrm{m}$. All species were deposited in the China University of Geosciences (Beijing). (1) Archaeoglobigerina cretacea d'Orbigny 1a, dorsal view; 1b, side view; 1c, ventral view. m222. (2) Hedbergella flandrini Porthault 2a, dorsal view; 2b, ventral view. m222. (3) Archaeoglobigerina blowi Pessagno 3a, dorsal view; 3b, side view; 3c, ventral view. m222. (4) Gavlinella sp. 4a, dorsal view; 4b, side view. m179. (5) Anomalinoides sp. 5a, dorsal view; 5b, side view. m169. (6) Haplophragmoides sp. 6a, dorsal view; 6b, side view; 6c, ventral view. m802. (7) Pullenia sp. 7a, ventral view; 7b, dorsal view. m810. (8) Clavulinoides sp. side view. m911. (9) Karrorulina hokkaidoana Takayanagi. side view. m913. (10) Karrorulina hokkaidoana Takayanagi. side view. m913.

[20,27]. Thus, the Songliao Basin was likely a near-shore continental basin with a relatively abundant and diverse foraminiferal fauna, but which were not continuous in their vertical distributions. This information supports the notion that these foraminifera came into the basin with marine water intrusions. Large lake transgressions occurred in the Songliao Basin during deposition of the Lower Nenjiang Formation. As a result, the lake level rose and its area enlarged [28]. At the same time, sea level also was higher. The ocean was not far away from the eastern margin of the Songliao Basin, and the paleo-Songliao lake was connected to the northwest Pacific periodically during phases of exceptionally high lake water and seawater levels.

The present work is a preliminary report on foraminifera in the Songliao Basin. An in-depth study of foraminifera containing other data will be presented in a future report along with a comprehensive explanation of seawater incur- sion events and paleoenvironmental change.

The authors acknowledge the help of Shen Yang and Gao Yuan with the laboratory work. Thanks also go to Professors Lord and two reviewers for helping to improve the paper. Thanks are given Professor Wang Chengshan for his help with and encouragement of this study. This work was supported by the National Basic Research Program of China (2006CB701403), the National Natural Science Foundation of China (40872016) and the Graduate Innovative Research Fundation of China University of Geosciences (Beijing).

1 Yang W L, Li Y K, Gao R Q. AAPG Bull, 1985, 69: 1101-1111

2 Huang Q H, Chen C R, Wang P Z, et al. Acta Micropalaeontol Sin, 1998, 15: 417-425

3 Zhang M M, Zhou J J, Liu Z C. Vertebr Palasiat, 1977, 15: 194-198

4 Gu Z W, Huang B Y, Chen C Z, et al. Fossil Lamellibranchiata of China (in Chinese). Beijing: Science Press, 1976. 1-522

5 Gu Z W, Yu J S. Palaeontol Sin, 1999, 188: 1-115

6 Gao R Q, He C Q, Qiao X Y. Acta Palaeontol Sin, 1992, 31: 19-30 
7 Gao R Q, He C Q, Qiao X Y. Cretaceous Non-marine Dinoflagellates, Chlorophytes and Acritarchs from the Songliao Basin (in Chinese). Nanjing: Nanjing University Press, 1992. 1-68

8 Wang P J, Du X D, Wang D P. Sediment Facies Palaeogeogr, 1995, 15: $14-20$

9 Ye S F, Wei K S. Earth Sci-J China Univ Geosci, 1996, 21: 267-271

10 Huang F T, Chi Y L, Huang Q H. Petrol Explor Dev, 1999, 26: 104-107

11 Li J, Mao S Z, Xu Y L, et al. Geoscience, 2000, 14: 267-272

12 Hou D J, Wang T G, Kong Q Y, et al. Chinese Sci Bull, 1999, 44: 560-563

13 Hou D J, Li M W, Huang Q H. Org Geochem, 2000, 31: 763-768

14 Feng Z H, Fang W, Wang X, et al. Sci China Ser D-Earth Sci, 2009, 52: 1559-1571

15 Sha J G. Cretaceous Res, 2007, 28: 146-170

16 Gao R Q, Zhao C B, Qiao X Y, et al. Cretaceous Oil Strata Palynology from Songliao Basin (in Chinese). Beijing: Geological Publishing House, 1999. 1-373

17 Ye D Q, Huang Q H, Zhang Y, et al. Cretaceous Ostracoda Biostratigraphy in Songliao Basin (in Chinese). Beijing: Petroleum Industry Press, 2002. 1-312
18 Gao Y F, Wang P J, Wang C S, et al. Acta Geol Sin, 2008, 82: 669675

19 Caron M. Cretaceous planktonic foraminifera. In: Bolli H M, Saunders J M, Perch-Nielsen K, eds. Plankton Stratigraphy (Vol 1). Cambridge: Cambridge University Press, 1989. 17-86

20 Kaiho K, Fujiwara O, Motoyama J. Mar Micropaleontol, 1993, 23: 13- 49

21 Cann J H, De Deckker P. J Paleontol, 1981, 55: 660-670

22 Wennrich V, Meng S, Schmiedl G. J Foramin Res, 2007, 37: 318-326

23 Sun Z C, Ceng X L, Chen K Z, et al. Acta Petrolei Sin, 1992, 13: 252-257

24 Wu N Q. Quat Sci, 1993, 3: 267-280

25 Li Y F, Li B Y, Wang G, et al. Chinese Sci Bull, 1997, 42: 10111014

26 Xiao Y K, Xiao J, Zhao Z Q, et al. Chinese Sci Bull, 2008, 53: 22072213

27 Nishia H, Takashimaa R, Hatsugai T. J Asian Earth Sci, 2003, 21: 867-886

28 Gao R Q, Zhao C B, Qiao X Y, et al. Cretaceous Oil Strata Palynology from Songliao Basin (in Chinese). Beijing: Geological Publishing House, 1999. 1-333

Open Access This article is distributed under the terms of the Creative Commons Attribution License which permits any use, distribution, and reproduction in any medium, provided the original author(s) and source are credited. 